\title{
Lower Cretaceous carbonate gravity-flow deposits from the Bohinj area (NW Slovenia): evidence of a lost carbonate platform in the Internal Dinarides
}

\author{
DUJE KUKOČ ${ }^{1}$, ŠPELA GORIČAN ${ }^{1}$ and ADRIJAN KOŠIR ${ }^{1}$
}

\begin{abstract}
Key-words. - Biancone limestone, Calcareous breccia, Radiolarians, Berriasian, Bled basin, Bohinj Formation
Abstract. - In the Bohinj area (NW Slovenia), a distinctive interval of carbonate gravity-flow deposits overlying the pelagic Biancone limestone was analyzed for microfacies and dated with radiolarians. This interval, newly described as the Bohinj Formation, consists of a $3 \mathrm{~m}$ thick carbonate breccia capped by a $4 \mathrm{~m}$ thick massive calcarenite. The breccia is composed of clasts of carbonate platform facies, isolated ooids and oncoids, and bioclasts of shallow-marine benthos. Intraclasts of pelagic calpionellid wackestone and rare chert clasts are also present. Radiolarians from the pelagic limestone below indicate a latest Tithonian to earliest Berriasian age, and those above indicate a Berriasian to Early Valanginian age. Paleogeographically, the area was part of the Bled basin, which had a relatively distal position on the Adriatic continental margin. This position is suggested by flysch-type deposits in the area that are Early Cretaceous in age and thus correlate with the Bosnian Flysch in the central Dinarides. The Bohinj Formation provides evidence of a carbonate platform that must have been located more internally but is now not preserved. This inferred platform (named the Bohinj Carbonate Platform) may have developed on top of a nappe stack, which formed during the early emplacement of the internal Dinaric units onto the continental margin. The platform correlates regionally with genetically similar isolated carbonate platforms of the Alpine - Dinaride - Carpathian orogenic system, e.g., with the Plassen Carbonate Platform in the Northern Calcareous Alps and the Kurbnesh Carbonate Platform in Albania.
\end{abstract}

Les dépôts gravitaires carbonatés d'âge crétacé inférieur de la région de Bohinj (nord-ouest de la Slovénie) : témoins d'une plate-forme carbonatée perdue dans les Dinarides internes

\begin{abstract}
Mots-clés. - Calcaire de Biancone, Brèche carbonatée, Radiolaires, Berriasien, Bassin de Bled, Formation de Bohinj
Résumé. - Dans la région de Bohinj au nord-ouest de la Slovénie un intervalle distinct de dépôts gravitaires carbonatés surmontant le calcaire pélagique de Biancone a été analysé pour le microfaciès et daté avec les radiolaires. Cet intervalle, défini ici comme la formation de Bohinj, est constitué de $3 \mathrm{~m}$ de brèche carbonatée et de $4 \mathrm{~m}$ de calcarénite massive. La brèche est composée de clastes de faciès calcaire de plate-forme, d'ooïdes et d'oncoïdes isolés ainsi que de bioclastes de benthos marin peu profond. Des intraclastes de wackestone pélagique à calpionelles et rares clastes de chert sont aussi présents. Les radiolaires présents dans le calcaire pélagique sous-jacent indiquent un âge tithonien sommital-crétacé basal et ceux au-dessus des calcarenites indiquent un âge berriasien-valanginien inférieur. Paléogéographiquement, la région appartenait au bassin de Bled, qui avait une position relativement distale sur la marge continentale de la plaque Adriatique. Cette position est suggérée par les dépôts du type flysch, qui dans la région sont d'âge crétacé inférieur et se corrèlent ainsi avec le flysch bosniaque dans les Dinarides centrales. La formation de Bohinj témoigne qu'une plate-forme carbonatée a dû exister en position plus interne mais elle n'est pas conservée. Cette plate-forme présumée (nommée la plate-forme carbonatée de Bohinj) a pu se développer au sommet d'un empilement de nappes qui s'est formé pendant la mise en place des unités dinariques internes sur la marge continentale. La plate-forme est comparable aux autres plates-formes carbonatées isolées dont l'origine est identique dans le système orogénique des Alpes, des Carpates et des Dinarides, par exemple la plate-forme carbonatée de Plassen dans les Alpes calcaires du Nord et la plate-forme carbonatée de Kurbnesh en Albanie.
\end{abstract}

\section{INTRODUCTION}

During the Jurassic and Cretaceous period, the major part of the External Dinarides was occupied by a vast carbonate platform system, the Dinaric Carbonate Platform, also known as the Adriatic Carbonate Platform or the Friuli Carbonate Platform [see Buser, 1996 and references therein]. In addition, several short-lived isolated carbonate platforms are known from the Internal Dinarides and Albanides (fig. 1). These smaller platforms were formed on top of ophiolitic nappes following their obduction onto the continental margin. Due to subsequent thrusting and erosion, some of these platforms are only fragmentarily preserved today or their existence is known exclusively from clasts in mass-flow deposits. Therefore, it is difficult to determine their size or even their exact life span. Upper Jurassic to Lower Cretaceous reef limestones and breccias associated with ophiolites have been documented in Bosnia [Charvet, 1978; Pamić and Hrvatović, 2000; Pamić et al., 2002], Vardar Zone [Karamata 2006, Robertson et al., 2009],

1. Paleontološki inštitut Ivana Rakovca ZRC SAZU, Novi trg 2, SI-1000 Ljubljana, Slovenia. (e-mail: duje.kukoc@zrc-sazu.si) Manuscript deposited on May 12, 2011; accepted on February 16, 2012. 


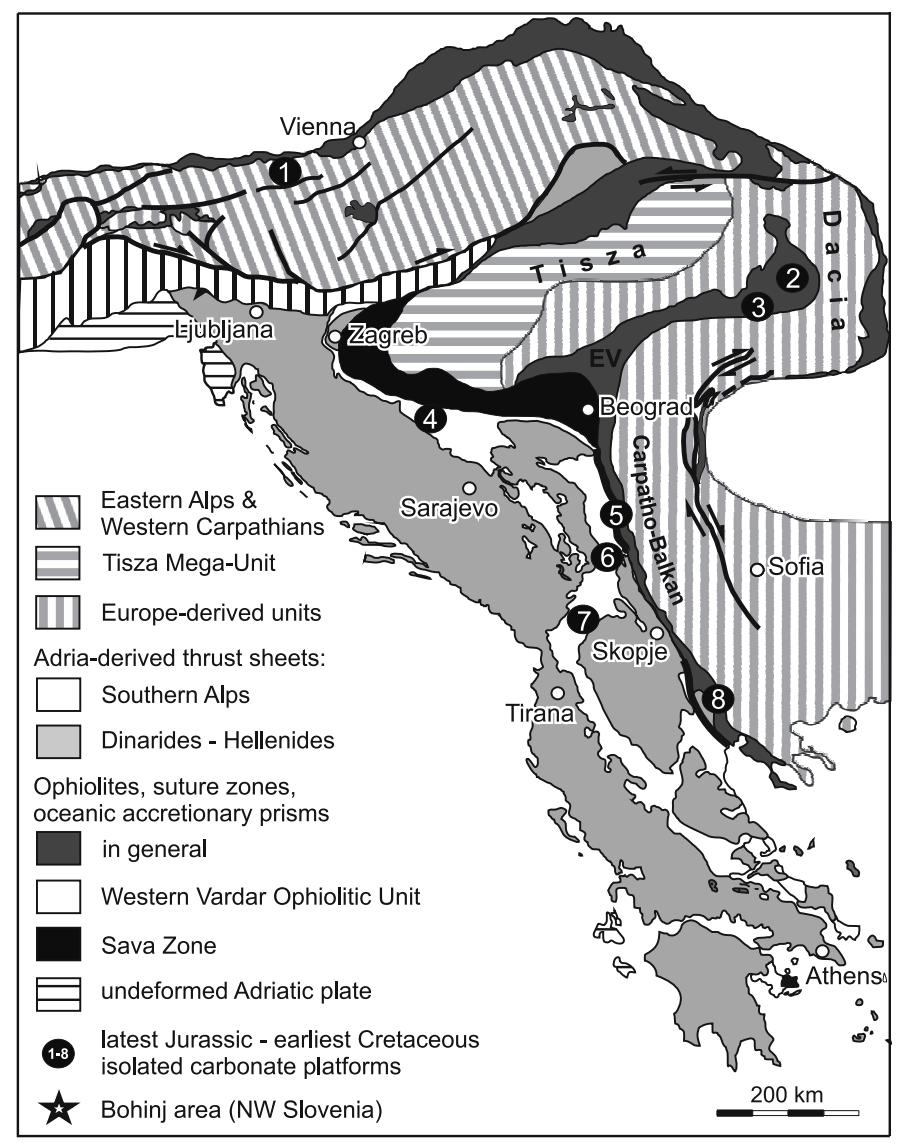

FIG. 1. - Major tectonic units of the Alps, Carpathians, Dinarides and Hellenides (simplified after Schmid et al. [2008] and Ustaszewski et al. [2009]) showing locations of shallow-water carbonates in the internal zones (for references see text): 1: Plassen Carbonate Platform (Northern Calcareous Alps, Austria); 2: Transylvanian ophiolites (Romania); 3: South Apuseni mountains (Romania); 4: Dinaride ophiolite belt (Bosnia); 5: Vardar Zone (Serbia); 6: Dinaride ophiolite belt (Krš Gradac section, SW Serbia); 7: Kurbnesh Carbonate Platform (Mirdita Zone, Albania); 8: Vardar Zone (Macedonia).

FIG. 1. - Principales unités tectoniques des Alpes, des Carpates, des Dinarides et des Hellénides (simplifié d'après Schmid et al. [2008] et Ustas zewski et al. [2009]) et localisation des carbonates néritiques dans les zones internes (pour les références voir texte). 1 : plate-forme carbonatée de Plassen (Alpes calcaires du Nord, Autriche) ; 2 : ophiolites de Transylvanie (Roumanie) ; 3 : monts Apuseni du Sud (Roumanie) ; 4 : zone ophiolitique des Dinarides (Bosnie) ; 5 : zone du Vardar (Serbie) ; 6 : zone ophiolitique des Dinarides (coupe Krš Gradac, sud-ouest de la Serbie); 7: plate-forme carbonatée de Kurbnesh (zone de Mirdita, Albanie); 8 : zone du Vardar (Macédoine).

Dinaride ophiolite belt [Radoičić et al., 2009], the South Apuseni mountains in Romania [Săsăran et al., 1999; Bortolotti et al., 2002] and Transylvanian Ophiolites [Schmid et al., 2008]. So far, only two isolated carbonate platforms from the Adriatic margin have been described more thoroughly, the Plassen Carbonate Platform in the Northern Calcareous Alps in Austria [Gawlick and Schlagintweit, 2006; Gawlick et al., 2009] and the Kurbnesh Carbonate Platform in the Mirdita Ophiolite Zone in Albania [Schlagintweit et al., 2008; Gawlick et al., 2008].

In the surroundings of Bohinj in NW Slovenia, a distinctive interval of resedimented limestone occurs between the pelagic Biancone limestone and the Lower Cretaceous flysch-type deposits. Cousin [1981] introduced the paleogeographical term Bled basin for this area because he noticed significant differences in stratigraphy compared with other deep-water successions in the Julian Alps. The most notable difference is the age of flysch deposits. The flysch-type sedimentation started in the ValanginianHauterivian in the Bled basin, but significantly later, in the Campanian to Maastrichtian in the other basins in the Julian Alps. This comparison led Cousin to correlate flysch deposits of the Bled basin with the Bosnian Flysch in the Central Dinarides and, thus, to assume a relatively internal position of this paleogeographic unit.

The importance of resedimented limestones in the Bohinj area has already been indicated in previous works. Budkovič [1978] described the general stratigraphic sequence of the area. He mentioned calcarenites with shallow-water components, and he used calcareous algae to determine their age as Late Jurassic. Cousin [1981] described microbreccias containing diverse shallow-water carbonate microfauna within deep-water Biancone limestones, which he dated with calpionellids as uppermost Tithonian to lowermost Berriasian.

The aims of this research are: 1) to study the topmost Jurassic to lowest Cretaceous succession of the Bled basin for radiolarian dating; 2) to examine the composition of gravity-flow deposits to determine the provenance and age of the clasts; and 3) to correlate this succession regionally.

\section{GEOLOGICAL SETTING}

The investigated section is located in the Julian Alps in northwestern Slovenia (fig. 2). During the Jurassic, this area was part of the Adriatic continental margin. Structurally, the Julian Alps form the eastern part of the southern Alps [Placer, 1999]. In this area, two thrusting phases are recognized: a NE to SW thrusting of the Paleogene Dinaric

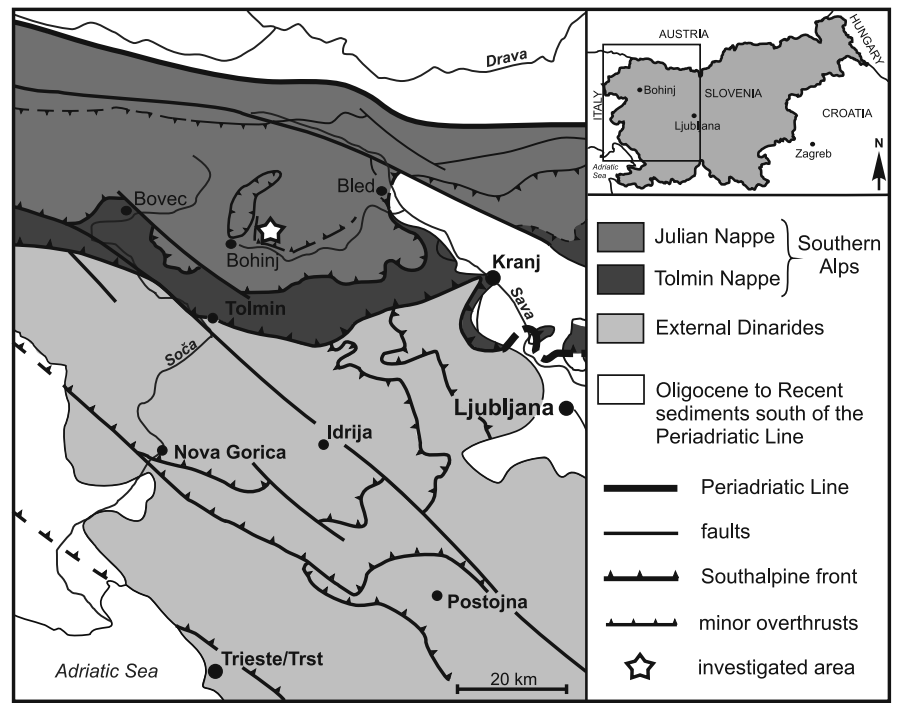

FIG. 2. - Macrotectonic subdivision of western Slovenia [simplified after Placer, 1999] showing the location of the investigated section.

FIG. 2. - Subdivision macrotectonique de la Slovénie occidentale [simplifié d'après Placer, 1999] et localisation de la coupe étudiée. 
phase, which was overprinted by the Neogene Southalpine phase characterized by a $\mathrm{N}$ to $\mathrm{S}$ thrusting [Placer, 1999]. From the aspect of the macrotectonic subdivision, NW Slovenia consists of three large nappes [Placer, 1999]. From bottom to top, these nappes are 1) the Trnovo nappe of the External Dinarides, where the successions of the Dinaric Carbonate Platform are exposed; 2) the Tolmin nappe, composed of the Tolmin basin successions; and 3) the Julian nappe, which is structurally the most complex and includes different paleogeographic units. Based on the Jurassic to Cretaceous stratigraphy, three paleogeographic units have been distinguished within the Julian nappe: the Julian high (a submarine plateau), the Bovec basin and the Bled basin [Cousin, 1981; Buser, 1996].
The general stratigraphy of the Bled basin (fig. 3a) is summarized from previous works [Härtel, 1920; Budkovič, 1978; Buser et al., 1979; Cousin, 1981; Buser 1986, 1987]. Lower Jurassic limestones with echinoderms (Hierlatz facies) laterally and vertically pass into massive oolitic limestone. The uppermost part consists of coarse-grained carbonate breccias that also include chert nodules, up to half a meter in size. Cousin [1981] informally named this interval the Ribnica breccia. The following lithostratigraphic unit comprises Middle and Upper Jurassic bedded radiolarian cherts and shales. The exact age of these deposits is yet to be determined. In the upper part, cherts and shales alternate with marly limestone and are overlain by approximately $50 \mathrm{~m}$ of laminated limestone, which passes into typical Upper

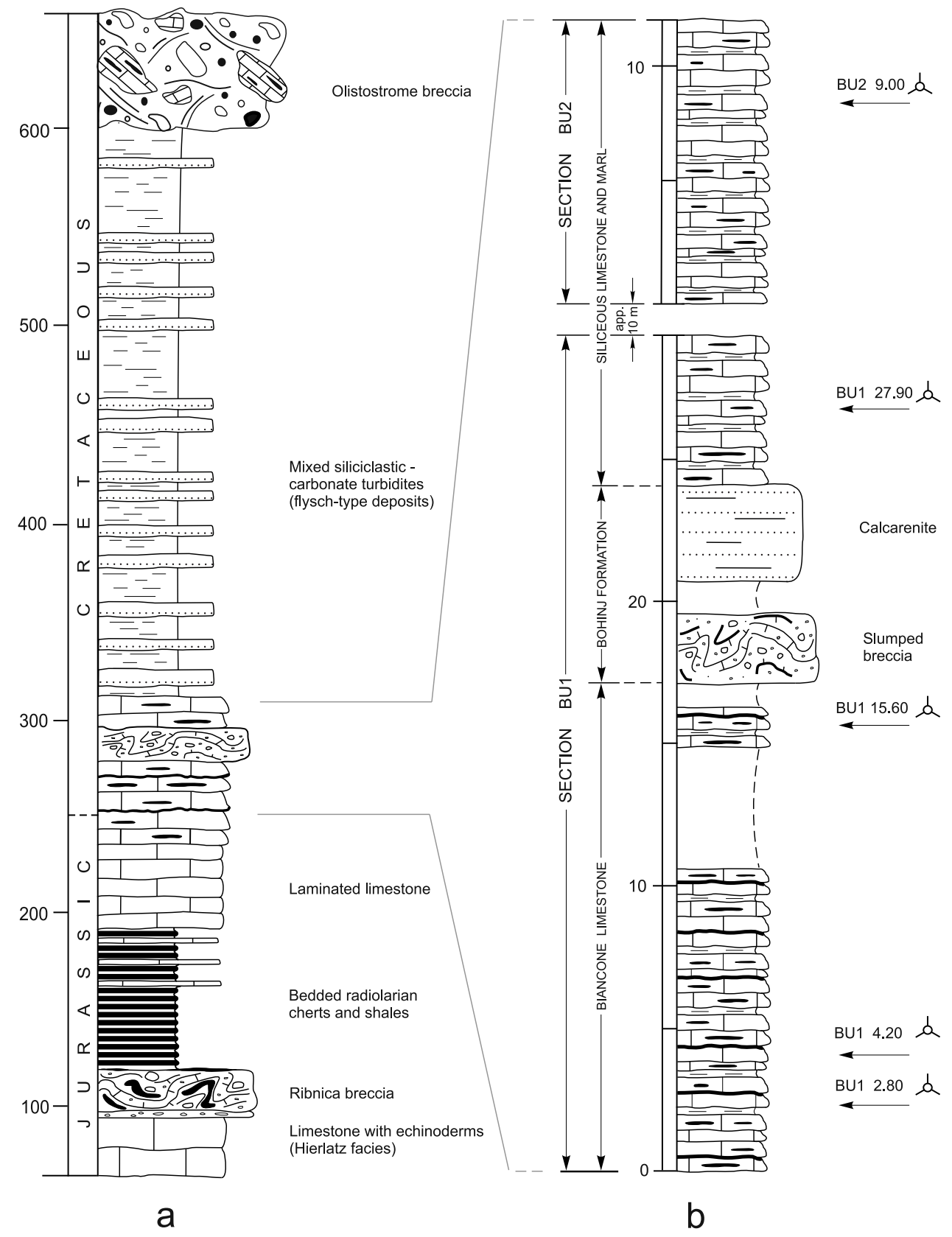

FIG. 3. - General stratigraphy of the Bled Basin (a) and detailed stratigraphic log of the investigated section near Srednja vas (b).

FIG. 3. - Stratigraphie générale du bassin de Bled (a) et colonne stratigraphique détaillée de la coupe étudiée près de Srednja vas (b). 
Tithonian Biancone limestone. The Biancone limestone is overlain by carbonate gravity-flow deposits, which are the main focus of our study.

The overlying succession starts with siliceous limestone with a significant proportion of marl and then passes into mixed siliciclastic-carbonate turbidites, referred to as flysch by previous authors. In places, olistostrome breccia containing blocks (a few $\mathrm{m}^{3}$ in size) of Biancone limestone occurs on top [Buser, 1986]. The matrix of the breccia is siliciclastic and is composed predominantly of quartz but also includes lithic grains, hornblende and plagioclase. Buser [1986] estimated the entire flysch sequence to be approximately $400 \mathrm{~m}$ thick. The flysch deposits near Bohinj have been dated with nannoplankton as ValanginianHauterivian [Buser et al., 1979].

\section{DESCRIPTION OF THE STUDIED SECTION AND DEFINITION OF THE BOHINJ FORMATION}

\section{General description}

An approximately $40 \mathrm{~m}$ thick section of pelagic limestones, including carbonate gravity-flow deposits (fig. 3b), is well exposed northeast of the Bohinj Lake, along the road from Srednja Vas to Uskovnica.

This section is subdivided into three lithostratigraphic units: 1) the Biancone limestone, 2) carbonate gravity-flow deposits, and 3) siliceous limestone with marl. The section combines two partial sections (marked BU1 and BU2), and the contact between them is tectonized. The missing part is estimated to be $10 \mathrm{~m}$ (fig. $3 \mathrm{~b}$ ).

The Biancone limestone is characterized by thin- to medium-bedded light gray to white limestone with individual beds up to $20 \mathrm{~cm}$ thick. Up to $5 \mathrm{~cm}$-thick discontinuous beds of dark gray chert and irregular shaped chert nodules are common. Intercalations of marl are also present. The predominant microfacies are radiolarian-rich wackestone and packstone (pl. I, fig.1). Parallel lamination is present in some layers. In places, normally graded calcarenites occur as several centimeters thick intercalations in micrite beds and contain up to $5 \mathrm{~mm}$ large clasts in the basal part (pl. I, fig. 2).

The second lithostratigraphic unit is described in the next chapter as the newly defined Bohinj Formation.

The third unit is reddish siliceous limestone similar to the Biancone limestone, although it differs significantly by its higher proportion of marl and the red color. At this section, the transition into the overlying flysch-type deposits is covered.

\section{Definition of the Bohinj Formation}

\section{Definition}

The Bohinj Formation is a characteristic interval of carbonate gravity-flow deposits that occur between the Biancone limestone below and the reddish siliceous limestones above. At the type locality, the Bohinj Formation consists of $3 \mathrm{~m}$ of carbonate breccia and $4 \mathrm{~m}$ of calcarenite (fig. $3 \mathrm{~b}$ ). Slump folds are present in the breccia. The calcarenite is massive and shows no internal folding or bedding.

\section{Type section}

Along the road from Srednja vas to Uskovnica (N 46 17,992 , E $\left.13^{\circ} 55,069^{\prime} ; \mathrm{H}=785 \mathrm{~m}\right)$.

\section{Lateral traceability}

The formation has been mapped in several locations NW and $\mathrm{NE}$ of the type locality within a distance of $6 \mathrm{~km}$.

\section{Name}

The formation is named after the broader area of the type locality.

\section{Age}

Latest Tithonian - Berriasian (according to Clypeina jurassica FAVRE found in breccia and radiolarian assemblages extracted from the deposits situated below and above the Bohinj Formation).

\section{Previous work}

Cousin [1981] informally named the entire mixed siliciclastic-carbonate succession above the Biancone limestone the Bohinj Formation (sandy marly limestone of Bohinj). In this paper, we restrict the name to the breccia and the calcarenite on top of the Biancone limestone.

\section{Microfacies of the Bohinj Formation}

The breccia consists primarily of matrix-supported angular to subangular shallow-water carbonate clasts. The largest clasts are up to $2 \mathrm{~cm}$ in diameter. The matrix is radiolarian-rich lime mudstone with sponge spicules and scarce calpionellids.

Most of the limestone clasts found in the breccia are bioclastic grainstones and bioclastic-peloidal packstones (pl. I, fig. 11). Clasts of algal wackestone and oncoid packstone are also present but rare. The skeletal grains in these clasts are miliolid and textulariid foraminifers, echinoderm fragments and algal fragments. The Dasyclad algae Clypeina jurassica FAVRE is found both in the clasts of algal wackestone and in the form of isolated fragments. It is characteristic of late Kimmeridgian to earliest Berriasian [Bassoullet, 1997]. The clasts of weakly cemented oolite show a thin fringe of early cement and pore spaces filled with the breccia matrix (pl. I, fig. 9).

Intraclasts of pelagic calpionellid wackestone are present. These interclasts also contain sponge spicules and rare planktonic foraminifers (pl. I, fig. 10). Radiolarians are not common in these clasts. Calpionellid species Calpionella alpina LORENZ is recognized. It is characteristic of the late Tithonian to earliest Valanginian [Remane, 1985].

In addition to common remains of Clypeina jurassica FAVRE (pl. I, figs 4, 5), the green algae Cayeuxia (pl. I, fig. 3) and fragments of sponges (pl. I, fig. 7), bryozoans, echinoderms and thick-shelled bivalves are identified as single bioclasts.

Well-developed concentric and radial ooids and oncoids are present as isolated grains (pl. I, fig. 4 and 8). Chert grains are also present.

Calcarenite is predominantly composed of shallow-water skeletal fragments and lithoclasts similar to those found 
in breccia. Grains of chert and glauconite are present but are less abundant than carbonate components.

The microfacies analysis reveals that the main source area of the resedimented limestone was a penecontemporaneous carbonate platform. Limestone clasts and isolated grains from the outer platform prevail, but lagoonal facies (algal wackestone) is also present.

\section{RADIOLARIAN BIOCHRONOLOGY}

The radiolarian fauna was analyzed from five samples of micritic limestone. The samples were processed with acetic acid (10\%) and then with hydrofluoric acid (5\%). The assemblages were dated with the zonation of Baumgartner et al. [1995], which, for this time interval, is mainly based on data by Jud [1994]. The species inventory is given in table I and illustrated in plate II. The stratigraphic position of the studied samples is shown in figure $3 \mathrm{~b}$. The generic names are adjusted according to the catalogue of Mesozoic radiolarian genera [O'Dogherty et al., 2009].

In all samples, spumellarians are slightly more abundant than nassellarians. Sponge spicules are common in all samples (megascleres prevail, but desmas and rhaxes are also present).

Eucyrtidiellum pyramis (AITA), found in samples BU1-4.20 and BU1-15.60, gives the shortest age assignment to UAZ 12 (early - early late Tithonian) - UAZ 13 (latest Tithonian - earliest Berriasian). Fultacapsa tricornis (JUD), in samples BU1-2.80 and BU1-27.90, gives a range from UAZ 13 (latest Tithonian - earliest Berriasian) to UAZ 16 (early Valanginian). Because samples BU1-4.20 and BU1-15.60 are stratigraphically above sample BU1-2.80, all three samples must belong to UAZ 13. Moreover, sample BU1-4.20 alone gives a precise assignment to UAZ 13, based on co-occurrence of Hiscocapsa kaminogoensis (AITA) and Praeparvicingula columna (RÜST) (FADs in UAZ 13) with Eucyrtidiellum pyramis (AITA) (LAD in UAZ 13). Sample BU1-27.90 is less well constrained but is still not younger than the early Valanginian. Sample BU2-9 may be somewhat younger, but typical genera first appearing in the late Valanginian (e.g., Cana, Crolanium, and Pseudocrolanium; see O'Dogherty et al., [2009]) have not been found.

The range of Hemicryptocapsa capita (TAN), according to Baumgartner et al. [1995], does not agree with the above determined age assignment. However, this species has already been found in a Berriasian assemblage [Matsuoka, 1998], and its occurrence is thus not conflicting. Similarly, Thanarla gutta JUD is not considered age diagnostic because similar forms exist throughout the Early Cretaceous (see, e.g., Fig. 103 in Matsuoka [1998]).

The Jurassic-Cretaceous boundary is comprised within the UAZ 13 [Baumgartner et al., 1995, p.1033] and, thus, cannot be strictly delineated with radiolarians. Because a several meters thick succession of the Biancone limestone is present below the studied samples, it is likely that the Bohinj Formation is earliest Cretaceous and not Tithonian in age.

\section{DISCUSSION}

The Biancone limestone is a common Upper Tithonian to Lower Cretaceous facies in the Julian Alps [Cousin, 1981; Buser; 1986, Šmuc; 2005; Rožič, 2009] and in other pelagic successions of the Mediterranean. This facies represents background pelagic sedimentation in a deeper-water environment, and it usually does not contain resedimented shallow-water clasts like the ones found in the Bled basin succession. Extraclasts and calcareous debris found in the Bled basin undoubtedly prove that the resedimented limestones are of platform origin. The Dinaric Carbonate Platform, located to the south, is now the only preserved carbonate platform in the area [Buser, 1989, 1996]. However, the Biancone limestone of the Tolmin basin, which was paleogeographically located proximally to the Dinaric Carbonate Platform (figs. 2, 4), consists of micrite without resedimented limestones [Buser, 1986; Rožič, 2009].

Furthermore, the age of the flysch-type sediments suggests that the Bled basin must have been located more internally than the Tolmin basin. Mixed siliciclastic - carbonate turbidites from the Bohinj area are Early Cretaceous in age (Hauterivian-Valanginian) [Buser et al., 1979], whereas the oldest flysch in the Tolmin basin is CampanianMaastrichtian in age [Cousin, 1981; Buser, 1986]. These Lower Cretaceous flysch-type deposits are best correlated with the Bosnian Flysch, more specifically, with the Vranduk Formation, which spans the latest Jurassic-Early Cretaceous [Blanchet et al. 1969; Mikes et al., 2008 and references therein]. The Vermoshi Flysch in Albania represents the southernmost part of the Vranduk Flysch [Meço and Aliaj, 2000; Marroni et al., 2009] and is regarded as the sedimentary marker of the Late Jurassic-Early Cretaceous tectonic phases related to the closure of the oceanic area between the Adria and Eurasia plates. If we consider the

TABLE I. - Occurrence of radiolarian taxa in studied samples. TABL. I - Distribution des taxons de radiolaires dans les échantillons étudiés.

\begin{tabular}{|c|c|c|c|c|c|c|}
\hline \multirow[b]{2}{*}{ Radiolarians } & \multirow{2}{*}{$\begin{array}{c}\text { UA Zones } \\
\text { (Baumgartner } \\
\text { et al, 1995) }\end{array}$} & \multicolumn{5}{|c|}{ Samples } \\
\hline & & $\begin{array}{l}\text { BU1- } \\
2.80\end{array}$ & $\begin{array}{l}\text { BU1- } \\
4.20\end{array}$ & $\begin{array}{l}\text { BU1- } \\
15.60\end{array}$ & $\begin{array}{l}\text { BU1- } \\
27.90\end{array}$ & $\begin{array}{l}\text { BU2- } \\
\text { 9.00 }\end{array}$ \\
\hline Archaeodictyomitra apiarium (RÜST) & $8-22$ & $\cdot$ & $\cdot$ & $\cdot$ & • & $\cdot$ \\
\hline Archaeodictyomitra excellens (TAN) & $11-22$ & - & & • & & - \\
\hline $\begin{array}{l}\text { Cinguloturris cylindra KEMKIN \& } \\
\text { RUDENKO }\end{array}$ & $12-17$ & & - & - & - & \\
\hline $\begin{array}{l}\text { Dicerosaturnalis dicranacanthos } \\
\text { (SQUINABOL) }\end{array}$ & $10-17$ & - & - & - & - & - \\
\hline Emiluvia chica (FOREMAN) & $3-18$ & - & •. & •. & •. & - \\
\hline Eucyrtidiellum pyramis (AITA) & $12-13$ & & • & • & & \\
\hline Fultacapsa tricornis (JUD) & $13-16$ & - & & & - & \\
\hline Hemicryptocapsa capita (TAN) & $17-18$ & & & - & • & \\
\hline Hiscocapsa asseni (TAN) & - & & & & & - \\
\hline Hiscocapsa hexagona (HORI) & - & & & & & - \\
\hline Hiscocapsa kaminogoensis (AITA) & $13-21$ & & • & & - & • \\
\hline Hiscocapsa lagenaria $(\mathrm{Wu} \& \mathrm{LI})$ & - & & & & • & \\
\hline Hiscocaps a pseudouterculus (AITA) & - & - & - & - & - & \\
\hline Loopus doliolum DUMITRICA & - & & & & - & \\
\hline Mictyoditra thiensis (TAN) & - & & & & - & \\
\hline Mirifusus minor BAUMGARTNER & $9-20$ & - & & & & \\
\hline Pantanellium squinaboli (TAN) & $11-22$ & - & •. & . & - & - \\
\hline Praeparvicingula columna (RÜST) & $13-20$ & & • & & • & \\
\hline $\begin{array}{l}\text { Praeparvicingula cosmoconica } \\
\text { (FoREMAN) }\end{array}$ & $13-22$ & & & & - & \\
\hline Pseudodictyomitra carpatica (LOZYNIAK) & $11-21$ & • & • & • & & • \\
\hline Ristola cretacea (BAUMGARTNER) & $12-17$ & - & - & & - & \\
\hline Tethysetta boesii (PARONA) & $9-22$ & - & - & - & & \\
\hline Thanarla gutta JUD & $20-21$ & - & - & - & - & - \\
\hline Thanarla praeventa PESSAGNO & - & & & & & - \\
\hline Tricolocapsa? campana KIESSLING & - & & • & & - & \\
\hline Xitus robustus $\mathrm{WU}$ & - & & & & - & \\
\hline $\begin{array}{l}\text { Age (UAZ) } \\
\end{array}$ & & $13-16$ & 13 & $12-13$ & $13-16$ & $11-17$ \\
\hline
\end{tabular}



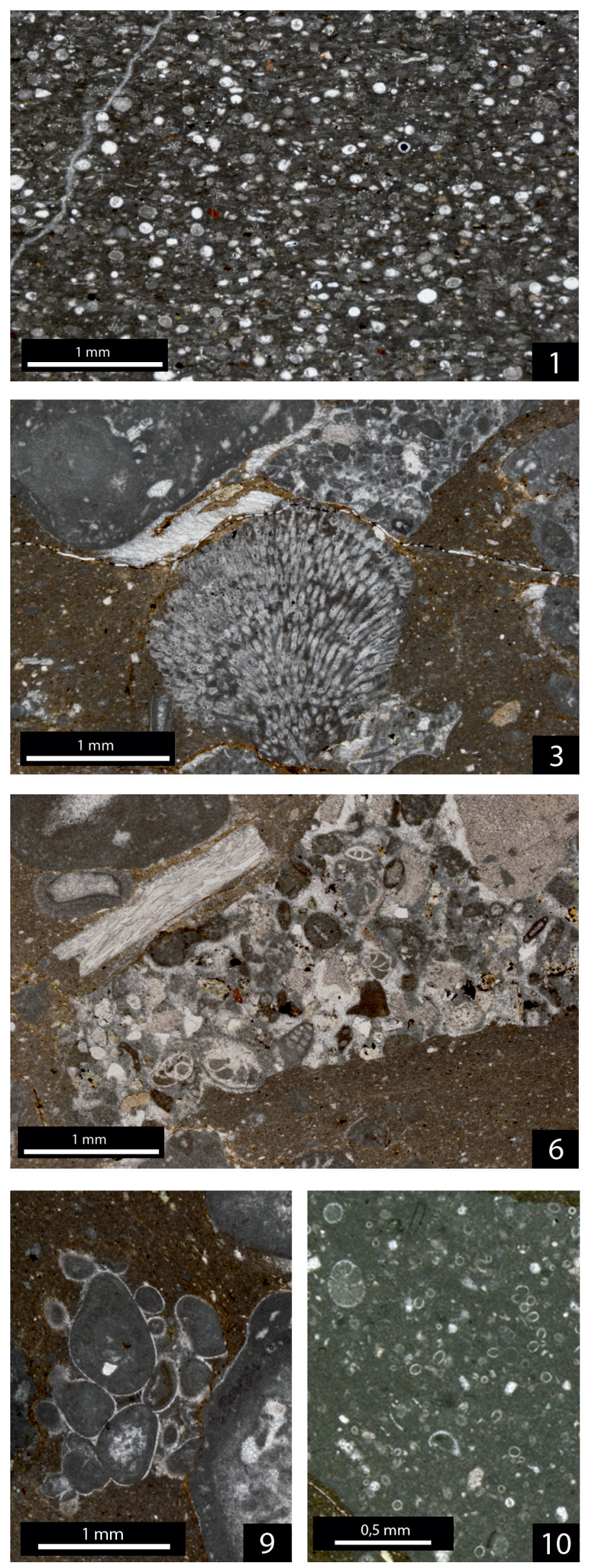
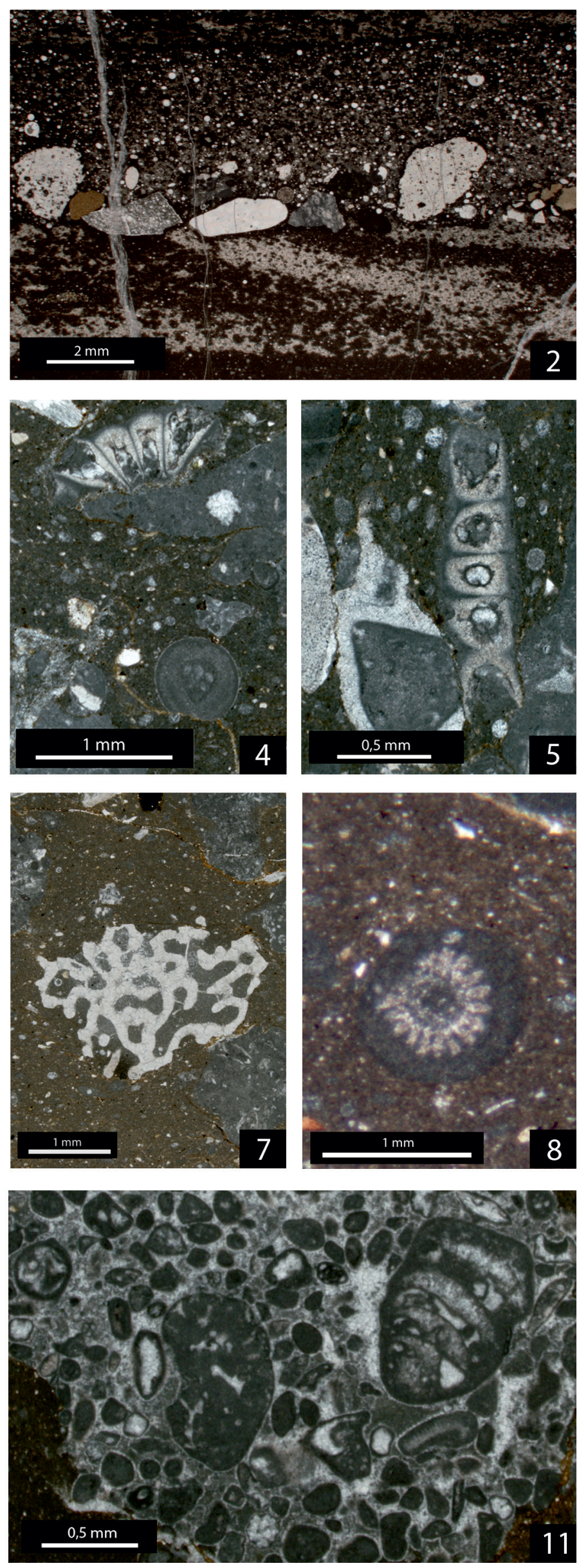
flysch-type deposits in the Bohinj area as the western continuation of the Vranduk Flysch, then it represents the westernmost outcrop of the Central Dinarides. The succession of the Bled basin also represents the innermost Dinaric zone in Slovenia. Geographically, the closest comparable unit is exposed on Mt. Ivanščica in NW Croatia, where Hauterivian to Albian mixed calcareous-siliciclastic turbidites (Oštrc Formation) directly overlie the Biancone limestone [Babić and Zupanič, 1978; Lužar-Oberiter et al., 2009]. Mt. Ivanščica clearly occupies a relatively internal position in the Dinarides because it is tectonically juxtaposed to the ophiolitic mélange of Mts. Medvednica and Kalnik [see, e.g., Tomljenović et al., 2008].

The contrasting stratigraphic evolutions of the Bled and Tolmin basins and similarities of the Bled basin with more internal Dinaric units imply that the Dinaric Carbonate Platform is unlikely to be the source of shallow-water carbonates in the Bled basin. The Julian platform, which existed in this area in the Late Triassic and Early Jurassic, was drowned and became a typical submarine plateau (the Julian high) with condensed sedimentation already in the Middle Jurassic [Šmuc, 2005 and references therein]. We interpret the breccia and calcarenite of the Bohinj Formation as evidence of a carbonate platform, which must have been located more internally but is now not preserved. This inferred platform, named the Bohinj Carbonate Platform, may have developed on top of a nappe stack, which formed during the early emplacement of the internal Dinaric units onto the continental margin of Adria (fig. 4). The Late Jurassic ophiolite emplacement has been well documented throughout the Dinarides [Dimitrijević, 1982, 1997; Pamić et al., 2002; Karamata, 2006, Schmid et al., 2008].

The paleogeographic position and stratigraphic range of the Bohinj Carbonate Platform can be deduced from a comparison with similar carbonate platforms from the AlpineDinaride-Carpathian mountain belt (fig. 1). The Plassen Carbonate Platform described from the Northern Calcareous Alps [Gawlick and Schlagintweit, 2006; Gawlick et al., 2009; Missoni and Gawlick, 2011] formed in a similar tectonic regime above cherty limestones and radiolarites and could be the stratigraphic counterpart of the Bohinj Carbonate Platform. The erosional products of the Plassen Carbonate Platform are incorporated in the Barmstein Limestone, which represents mass-flow deposits with shallow-water bioclasts and reefal limestone intercalated in pelagic limestones of the Oberalm Formation [Gawlick et al., 2005; Gawlick et al., 2009]. At its type locality, the whole sedimentary cycle of the Plassen Carbonate Platform lasted

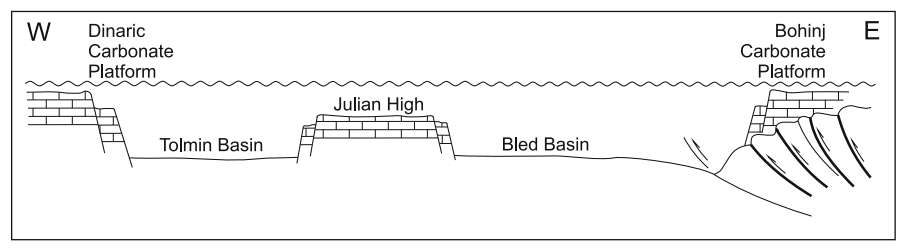

FIG. 4. - Schematic cross-section of paleogeographic units in western Slovenia in the Berriasian.

Fig. 4. - Coupe schématisée des unités paléogéographiques en Slovénie occidentale pendant le Berriasien.

from the early Kimmeridgian until the late Berriasian [Gawlick and Schlagintweit, 2006]. The Bohinj carbonate platform is likely to have the same stratigraphic range. Similar carbonate facies characterized both platforms with the exception of coral and stromatoporoid fragments that were only found in the Plassen Carbonate Platform. The Bohinj Formation is correlative to the Upper Tithonian-Berriasian Barmstein Limestone, which contains the erosional products of the Plassen Carbonate Platform [Gawlick et al., 2005].

Another well-documented example is the Kurbnesh Carbonate Platform in the Mirdita Zone in Albania. This platform is also known only from clasts contained in mass-flow deposits. We note that these mass-flow deposits overlie basalts and ophiolitic mélange, whereas the Bohinj Formation is part of a pelagic continental-margin sequence. The reported stratigraphic range of the Kurbnesh Carbonate Platform is Kimmeridgian?-Tithonian [Schlagintweit et al., 2008]. The Kurbnesh Carbonate Platform is followed stratigraphically by the autochthonous Munella Carbonate Platform, which existed from the Late BerriasianValanginian to Early Aptian. Therefore, the Bohinj Carbonate Platform correlates with the Kurbnesh Carbonate Platform or, less probably, with the base of the Munella Carbonate Platform.

The same genetic model has been proposed for several other occurrences of platform carbonates in the AlpineDinaride-Carpathian mountain belt (fig. 1). Shallow-water carbonates accumulated locally after the emplacement of ophiolitic nappes onto the continental margin [Schmid et al., 2008; Gawlick et al., 2008; Gawlick et al., 2009]. Most of the newly formed carbonate platforms are known only from fragments of their reefs [Pamić and Hrvatović, 2000; Bortolotti et al., 2002; Karamata, 2006]. Among

PLATE I. - Microfacies from the studied section: 1: pelagic Biancone limestone, radiolarian packstone; 2: graded layer in Biancone limestone with grains of chert at the base and accumulation of radiolarian skeletons above; silicified parts (lighter area) are visible below and above; 3 : bioclast of Cayeuxia in mud-supported breccia and clasts of bioclastic packstone with textulariids; 4: isolated Clypeina jurassica FAVRE and an isolated ooid in matrix-supported breccia; 5: bioclast of Clypeina jurassica FAVRE; 6: bioclastic packstone containing foraminifers and echinoderm fragments; 7: bioclast of calcareous sponge; 8: matrix with coated echinoid spine; 9: clast of oolite weakly cemented with a thin fringe of early cement, pore spaces are filled with the breccia matrix; 10: clast of pelagic wackestone containing abundant calpionellids; 11: clast of bioclastic-peloidal packstone with benthic foraminifers.

PL. I. - Microfaciès de la coupe étudiée. 1 : Calcaire pélagique de Biancone, packstone à radiolaires ; 2 : couche granoclassée dans le calcaire de Biancone avec les grains de chert à la base et accumulation des squelettes de radiolaires en haut; les parties silicifiées (champs clairs) sont visibles en bas et en haut ; 3 : bioclaste de Cayeuxia et clastes de packstone bioclastique avec textulariidés dans la brèche ; 4 : Clypeina jurassica FAVRE isolée et un oö̈de isolé dans la brèche supportée par la matrice; 5 : bioclaste de Clypeina jurassica FAVRE; 6 : packstone bioclastique contenant des foraminifères et des fragments d'échinodermes ; 7 : bioclaste d'éponge calcaire; 8 : matrice avec une épine d'échinoid enveloppée dans un ooüde ; 9 : claste oolitique faiblement cimenté par une fine frange de ciment précoce, les pores sont remplis avec la matrice de la brèche; 10 : claste de wackestone pélagique contenant d'abondants calpionelles ; 11 : claste de packstone à bioclastes et à peloüdes avec des foraminifères benthiques. 

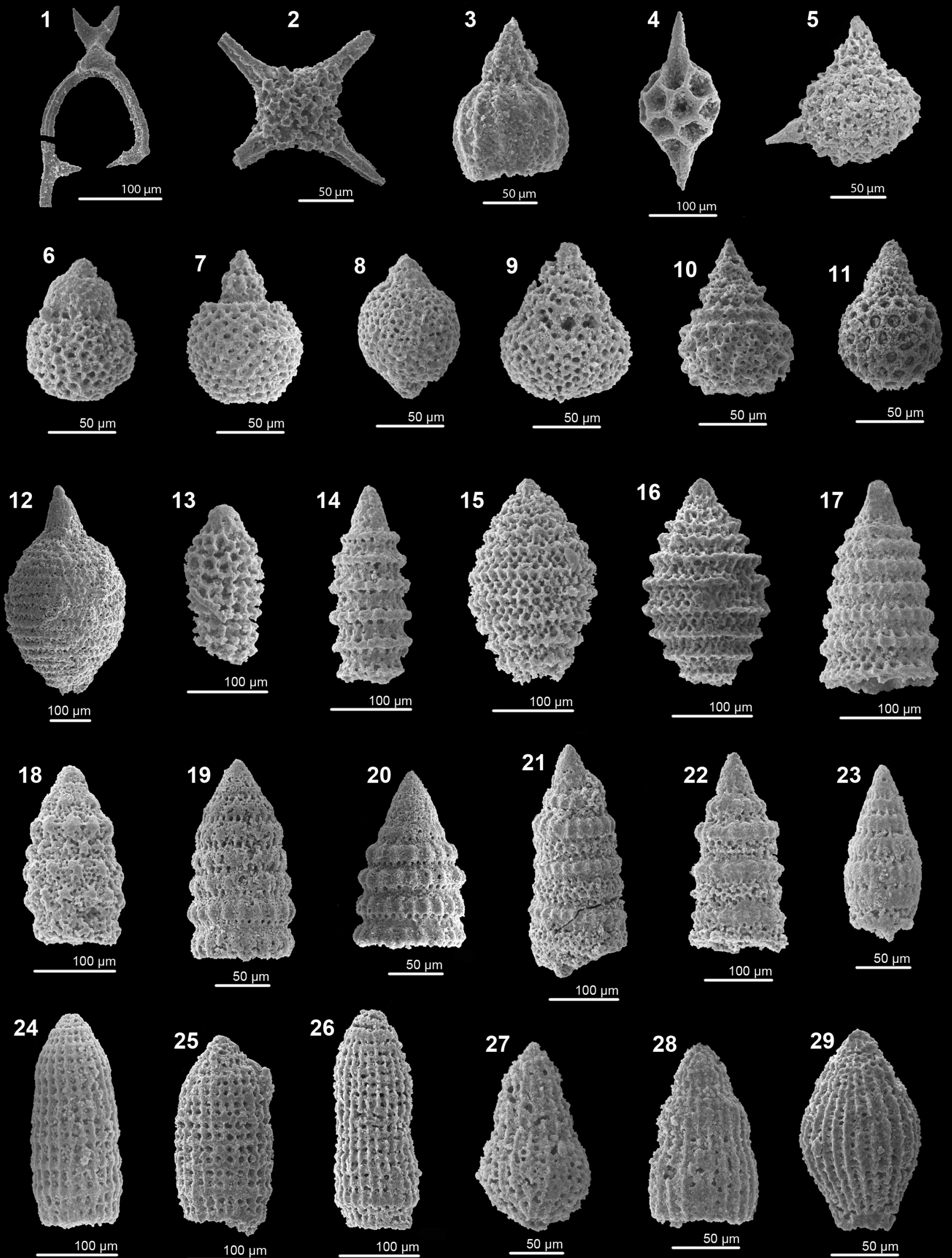
those platforms that formed on the western, i.e., Adriatic margin, a detailed stratigraphic investigation has been made only for the Plassen Carbonate Platform, the Kurbnesh Carbonate Platform and, in this paper, the Bohinj Carbonate Platform.

\section{CONCLUSIONS}

1) A distinctive interval of carbonate breccia and calcarenite, occurring in a succession of pelagic limestones, is described and defined as the Bohinj Formation. The latest Tithonian-Berriasian age of the formation is constrained with radiolarians.

2) The succession was deposited in the Bled Basin, which occupied a relatively distal position on the Adriatic continental margin and was distant from the stable Dinaric Carbonate Platform. Penecontemporaneous shallow-water carbonate clasts in the breccia indicate the existence of another carbonate platform, named the Bohinj Carbonate Platform.

3) Based on regional correlations, we conclude that the Bohinj Carbonate Platform was a small, isolated platform developed on top of an uplifted nappe stack, which formed during the early emplacement of the internal Dinaric units onto the continental margin.

4) Two examples of such isolated platforms have so far been studied in detail, the Plassen Carbonate Platform from the northern Calcareous Alps in Austria and the Kurbnesh Carbonate Platform from the Mirdita Zone in Albania. The Bohinj Formation is a stratigraphic counterpart of formations that contain erosional products of these platforms, i.e., the Barmstein limestone and the Kurbnesh Formation, respectively.

5) The gravity-flow deposits of the Bohinj Formation document platform erosion, but the entire time span of the platform could not be determined directly. The correlation with the well-dated and in situ preserved Plassen Carbonate Platform suggests that the Bohinj Carbonate Platform may have existed from the Early Kimmeridgian to the Late Berriasian.

Acknowledgments. - This research was funded by the Slovenian Research Agency (project no. J1 - 4198). We are thankful to Kata Cvetko Barić for preparing the thin sections. Two reviewers, Hans-Jürgen Gawlick and Atshushi Matsuoka, and the editor Taniel Danelian provided helpful comments that improved this manuscript.

\section{References}

BABIĆ LJ. \& ZuPANIČ J. (1978). - Mlađi mezozoik Ivanščice [in Croatian]. In: L.J. BABIĆ and V. Jelaska, Eds., Vodič ekskurzije 3. - Skupa sedimentologa Jugoslavije. Croatian Geological Society, Zagreb, 11-23.

Bassoullet J.-P. (1997). - Algues Dasycladales. Distribution des principales espèces. In: E. CARiou and P. HantzPergue, Coord., Groupe Français d'Étude du Jurassique. Biostratigraphie du Jurassique ouest-européen et méditerranéen: Zonations parallèles et distribution des invertébrés et microfossiles. - Bull. Centre Rech. Elf Explor. Prod., Mém. 17, 339-342.

Baumgartner P.O., Bartolini A., Carter E.S., Conti M., Cortese G., Danelian T., De Wever P., Dumitrica P., Dumitrica-Jud R., Goričan Š., Guex J., Hull D.M., Kito N., Marcucci M., Matsuoka A., Murchey B., O'Dogherty L., SAVARy J., Vishnevskaya V., Widz D. \& Yao A. (1995). - Middle Jurassic to Early Cretaceous radiolarian biochronology of Tethys based on Unitary Associations. In: P.O. Baumgartner, L. O'DOgherty, Š. Goričan, E. Urquhart, A. Pillevuit \& P. De Wever, Eds. Middle Jurassic to Lower Cretaceous radiolaria of Tethys: occurrences, systematics, biochronology. - Mémoires de Géologie (Lausanne), 23, 1013-1038.
Blanchet R., Cadet J.-P., Charvet J. \& Rampnoux J.-P. (1969). - Sur l'existence d'un important domaine de flysch tithonique - crétacé inférieur en Yougoslavie: l'unité du flysch bosniaque. - Bull. Soc. géol. Fr., (7), XI, 871-880.

Bortolotti V., Marroni M., Ionel N., Pandolfi L., Principi G.F. \& SACCANI E. (2002). - Geodynamic implications of Jurassic ophiolites associated with island-arc volcanics, South Apuseni mountains, western Romania. - Internat. Geol. Rev., 44, 938-955.

Budkovič T. (1978). - Stratigrafija Bohinjske doline. The stratigraphic sequence of the Bohinj Valley. - Geologija, 21, 239-244.

BUSER S. (1986). - Tolmač k Osnovni geološki karti SFRJ 1:100,000 listov Tolmin in Videm (Udine). - Savezni geološki zavod, Beograd, $103 \mathrm{pp}$.

BUSER S. (1987). - Osnovna geološka karta SFRJ 1:100,000, list Tolmin in Videm. - Savezni geološki zavod, Beograd.

BUSER S. (1989). - Development of the Dinaric and Julian carbonate platforms and the intermediate Slovenian Basin (NW Yugoslavia). In: G.B. Carulli, F. CuCChi and C.P. Radrizzani, Eds., Evolution of the karstic carbonate platform: relation with other periadriatic carbonate platforms. - Mem. Soc. Geol. Ital., 40 (1987), 313-320.

Plate II. - Latest Tithonian to earliest Cretaceous radiolarians. The sample number and SEM number are indicated for each illustration.

PL. II. - Radiolaires d'âge tithonien sommital à crétacé basal. Pour chaque figure le numéro de l'échantillon et le numéro du cliché MEB sont précisés.

1. Dicerosaturnalis dicranacanthos (SoUINABOL), BU1-15.60, 110115.

2. Emiluvia chica (ForemAN), BU1-4.20, 110232.

3. Eucyrtidiellum pyramis (AITA), BU1-15.60, 110123.

4. Pantanellium squinaboli (TAN), BU1-27.90, 100404.

5. Fultacapsa tricornis (JUD), BU1-27.90, 100458.

6. Tricolocapsa? campana KIESSLING, BU1-27.90, 100409.

7. Hiscocapsa pseudouterculus (AITA), BU1-27.90, 100424.

8. Hemicryptocapsa capita (TAN), BU1-27.90, 100446.

9. Hiscocapsa lagenaria (WU and LI), BU1-27.90, 100443.

10. Hiscocapsa kaminogoensis (AITA), BU1-4,20, 110244.

11. Hiscocapsa hexagona (HoRI), BU2-9, 100616.

12. Mirifusus minor BaUmGarTnER, BU1-2.80, 100332.

13. Ristola cretacea (BAUMGARTNER), BU1-27.90, 100421.

14. Praeparvicingula columna (RÜST), BU1-27.90, 100410.

17. Praeparvicingula cosmoconica (ForEMAN), BU1-27.90, 100452

18. Xitus robustus Wu, BU1-27.90, 100520.

19, 20. Pseudodictyomitra carpatica (LOZYNIAK), 19. BU1-2.80, 100308,

20. BU1-2.80, 100306.

21, 22. Cinguloturris cylindra Kemkin and Rudenko, 21. BU1-27.90, 100414, 22. BU1-27.90, 100518.

23. Loopus doliolum DumitricA, BU1-27.90, 100434.

24, 25. Archaeodictyomitra apiarium (RÜST), 24. BU1-27.90, 100527, 25.

BU2-9, 100609.

26. Archaeodictyomitra excellens (TAN), BU1-2.80, 100314

27. Mictyoditra thiensis (TAN), BU1-27.90, 100456.

28. Thanarla praeventa PESSAGNO, BU2-9, 100629.

29. Thanarla gutta JUD, BU1-4.20, 110248.

15, 16. Tethysetta boesii (PARONA), 15. BU1-2.80, 100309, 16. BU1-4,20, 110206. 
BUSER S. (1996). - Geology of western Slovenia and its paleogeographic evolution. In: K. Drobne, Š. GoriČan \& B. KotniK, Eds., The role of impact processes in the geological and biological evolution of planet earth. - Internat. workshop Postojna 1996 , 111-123.

Buser S., PAVŠIČ J. \& RADOIČIĆ R. (1979). - Spodnjekredne plasti v Bohinju. Rudarsko - metalurški zbornik, 26, 4, 385-393.

Charvet J. (1978). - Essai sur un orogène alpin - Géologie des Dinarides au niveau de la transversale de Sarajevo (Yougoslavie). - Soc. Géol. Nord, 2, 496 pp.

Cousin M. (1981). - Les rapports Alpes - Dinarides. Les confins de 1'Italie et de la Yougoslavie. - Soc. Géol. Nord, 5, vol. 1: 521 pp., vol. 2: Annexe, $521 \mathrm{pp}$.

Dimitrijević M.D. (1982). - Dinarides: an outline of the tectonics. - Earth Evol. Sci., 3, 4-23.

Dimitrijević M.D. (1997). - Geology of Yugoslavia. - Geoinstitute, Beograd, $187 \mathrm{pp}$.

Gawlick H.J., Frisch W., Hoxha L., Dumitrica P., Krystyn L., Lein, R., Missoni S. \& Schlagintweit F. (2008). - Mirdita Zone ophiolites and associated sediments in Albania reveal Neotethys Ocean origin. - Int. J. Earth. Sci. (Geol. Rundsch), 97, 865-881.

Gawlick H.J., Missoni S., Schlagintweit F., Suzuki H., Frisch W., Krystyn L., Blau J. \& LeIN R. (2009). - Jurassic tectonostratigraphy of the Austroalpine Domain. - J. Alp. Geol., 50, 1-152.

Gawlick H.J. \& Schlagintweit F. (2006). - Berriasian drowning of the Plassen carbonate platform at the type - locality and its bearing on the early Eoalpine orogenic dynamics in the Northern Calcareous Alps (Austria). - Int. J. Earth Sci. (Geol. Rundsch.), 95 451-462.

Gawlick H.J., Schlagintweit F. \& Missoni S. (2005). - Die Barmsteinkalke der Typlokalität nordwestlich Hallein (hohes Tithonium bis tieferes Berriasium; Salzburger Kalkalpen) - Sedimentologie, Mikrofazies, Stratigraphie und Mikropaläontologie: neue Aspekte zur Interpretation der Entwicklungsgeschichte der Ober Jura - Karbonatplattform und der tektonischen Interpretation der Hallstätter Zone von Hallein - Bad Dürrnberg. - Neues Jahrb. Geol. Paläontol., Abhandlungen, 236, 351-421.

HÄRTEL F. (1920). - Stratigraphische und Tektonische Notizen über das Wocheiner - Juragebeit. - Verh. Geol. R. A., 8-9, 134-153.

JUD R. (1994). - Biochronology and systematics of Early Cretaceous radiolaria of the western Tethys. - Mémoires de Géologie (Lausanne), 19, $147 \mathrm{pp}$.

Karamata S. (2006). - The geological development of the Balkan Peninsula related to the approach, collision and compression of Gondwana and Eurasian units. In: A.H.F. Robertson \& D. Mountrakis, Eds., Tectonic development of the eastern Mediterranean region. - Geol. Soc., London, Sp. Publ., 260, 155-178.

LuŽar-Oberiter B., Mikes T., von Eynatten H. \& Babić Lj. (2009). Ophiolitic detritus in Cretaceous clastic formations of the Dinarides (NW Croatia): evidence from $\mathrm{Cr}$-spinel chemistry. - Int. J. Earth. Sci. (Geol. Rundsch), 98, 1097-1108.

Marroni M., Pandolfi L., Onuzi K., Palandri S. \& Xhomo A. (2009). Ophiolite-bearing Vermoschi Flysch (Albanian Alps, northern Albania): Elements for its correlation in the frame of DinaricHellenic belt. - Ofioliti, 34, 95-108.

Matsuoka A. (1998). - Faunal composition of earliest Cretaceous (Berriasian) radiolaria from the Mariana Trench in the western Pacific. In: A. Matsuoka, Ed., Proceedings of the Sixth Radiolarian Symposium. - News of Osaka Micropaleontologists, Special Volume, 11, $165-187$.

Meço S. \& Aliaj S. (2000). - Geology of Albania. - Gebrüder Bornträger, Berlin, Stuttgart, $246 \mathrm{pp}$.
Mikes T., Christ D., Petri R., Dunkl I., Frei D., BÁldi-Beke M., Reitner J., Wemmer K., Hrvatović H. \& Von Eynatten H. (2008). Provenance of the Bosnian Flysch. - Swiss J. Geosci., 101, Supplement 1, S31-S54.

Missoni S. \& GAwlick H.J. (2011). - Jurassic mountain building and Mesozoic-Cenozoic geodynamic evolution of the Northern Calcareous Alps as proven in the Berchtesgaden Alps (Germany). Facies, 57, 137-186.

O’Dogherty L., Carter E. S., Dumitrica P., Goričan Š., De Wever P., Bandini A. N., Baumgartner P. O. \& Matsuoka A. (2009). Catalogue of Mesozoic radiolarian genera. Part 2: Jurassic Cretaceous. In: L. O'DOgherty, Š. GoriČAn and P. DE WeVER, Eds., Catalogue of Mesozoic radiolarian genera. - Geodiversitas, 31, 271-356.

Pamić J. \& Hrvatović H. (2000). - Dinaride Ophiolite Zone (DOZ). In: J. Pamić \& B. Tomluenović, Eds., Pancardi 2000 Fieldtrip Guidebook. - Vijesti, 37, 2, 60-68.

PAmić J., Tomljenović B. \& Balen D. (2002). - Geodynamic and petrogenetic evolution of Alpine ophiolites from the central and NW Dinarides: an overview. - Lithos, 65, 113-142.

Placer L. (1999). - Contribution to the macrotectonic subdivision of the border region between southern Alps and External Dinarides. Geologija, 41, 223-255.

RADOIČIĆ R., JovANović D. \& SudAR M. (2009). - Stratigraphy of the Krš Gradac section (SW Serbia). - Annal. Géol. Péninsule Balkanique, 70, 23-41.

Remane J. (1985). - Calpionellids. In: H.M. Bolli, J.B. Saunders and K. Perch-Nielsen, Eds., Plankton stratigraphy. - Cambridge University Press, 555-572.

Robertson A., Karamata S. \& ŠArić K. (2009). - Overview of ophiolites and related units in the Late Palaeozoic - Early Cenozoic magmatic and tectonic development of Tethys in the northern part of the Balkan region. - Lithos, 108, 1-36.

Rožıč B. (2009). - Perbla and Tolmin formations: revised Toarcian to Tithonian stratigraphy of the Tolmin Basin (NW Slovenia) and regional correlations. - Bull. Soc. géol. Fr, 180, 411-430.

SĂSĂRAN E., Hosu A., SPĂLnăCAN R. \& BuCUR I. (1999). - Microfacies, microfosils and sedimentary evolution of the Săndulesti limestone formation in Cheile Turzii (Apuseni mountains, Romania). Acta Palaeontol. Romaniae, 2, 453-462.

Schlagintweit F., Gawlick H.J., Missoni S., Hoxha L., Lein R. \& Frisch W. (2008). - The eroded Late Jurassic Kurbnesh carbonate platform in the Mirdita Ophiolite Zone of Albania and its bearing on the Jurassic orogeny of the Neotethys realm. - Swiss J. Geosci., 101, 125-138.

Schmid M.S., Bernoulli D., Fügenschuh B., Matenco L., Schefer S., Schuster R., Tischler M. \& Ustaszewski K. (2008). - The Alpine-Carpathian-Dinaridic orogenic system: correlation and evolution of tectonic units. - Swiss J. Geosci., 101, 139-183.

ŠMUC A. (2005). - Jurassic and Cretaceous stratigraphy and sedimentary evolution of the Julian Alps, NW Slovenia. - Zalo ba ZRC/ ZRC Publishing, ZRC SAZU, Ljubljana, 98 pp.

Tomljenović B., Csontos L., Márton E. \& Márton P. (2008). - Tectonic evolution of the northwestern Internal Dinarides as constrained by structures and rotation of Medvednica mountains, North Croatia. In: S. SiEgesmund, N. FÜGENSCHUH AND B. FroitzheIM, Eds, Tectonic aspects of the Alpine-Dinaride-Carpathian system. Geol. Soc. London, Sp. Publ., 298, 145-167.

Ustaszewski C., Schmid M.S., Lugović B., Schuster R., Schaltegger U., Bernoulli D., Hottinger L., Kounov A., Fügenschuh B. \& SCHEFER S. (2009). - Late Cretaceous intra oceanic magmatism in the internal Dinarides (northern Bosnia and Herzegovina): Implications for the collision of the Adriatic and European plates. - Lithos, 108, 106-125. 